\title{
Ulgi w zapłacie składki zdrowotnej dla przedsiębiorców
}

\section{Reductions for Entrepreneurs in Health Insurance Contributions}

Streszczenie. Tematem niniejszego artykułu są ulgi w zapłacie składki zdrowotnej dla przedsiębiorców. Tylko przedsiębiorcy należący do określonych grup społecznych mogą skorzystać z analizowanych ulg. Omawiane ulgi mają zastosowanie wyłącznie do osób pobierających emeryturę lub rentę oraz osób zaliczanych do umiarkowanego lub znacznego stopnia niepełnosprawności. Ustawodawca uzależnił możliwość skorzystania z ulg w zapłacie składki zdrowotnej m.in. od uzyskiwanego dochodu przez podmioty opłacające składkę, a także od przychodu uzyskiwanego z prowadzonej działalności gospodarczej, ewentualnie od opłacania podatku dochodowego w formie karty podatkowej. Osoby niepełnosprawne mogą także skorzystać z dodatkowej ulgi przewidzianej wyłącznie dla nich. W niniejszym opracowaniu poddane zostały analizie przepisy regulujące możliwość skorzystania z powyższych ulg. W szczególności wskazano na ich wadliwą konstrukcję, która powoduje, że tylko nieliczni ubezpieczeni mogą z nich skorzystać.

Słowa kluczowe: ulgi; składka zdrowotna; przedsiębiorcy. 


\begin{abstract}
This paper describes the reductions for entrepreneurs in health insurance contributions. Only entrepreneurs from specific social groups can take advantage of said reductions. They apply only to people retired, on pensions or handicapped. The reductions are also dependent on the potential recipient's income and revenue of the company. Handicapped entrepreneurs can benefit from some additional privileges as well. Author analyzes the legal regulations behind these reductions and exposes their shortcomings which cause the benefits to be rarely used.
\end{abstract}

Keywords: reductions; health insurance contribution; entrepreneurs.

\title{
1. Wprowadzenie
}

W obecnym stanie prawnym składka na ubezpieczenie zdrowotne została uregulowana w rozdziale 2 działu IV ustawy z dnia 27 sierpnia 2004 r. o świadczeniach opieki zdrowotnej finansowanych ze środków publicznych ${ }^{1}$. Składka zdrowotna w polskim systemie ochrony zdrowia istnieje nieprzerwanie od 1 stycznia 1999 r. Została ona wprowadzona ustawą z dnia 6 lutego 1997 r. o powszechnym ubezpieczeniu zdrowotnym². Do 31 grudnia 1998 r. świadczenia zdrowotne były finansowane przede wszystkim z budżetu państwa. W związku z tym wprowadzenie składki zdrowotnej całkowicie przekształciło system finansowania ochrony zdrowia w Polsce.

Ustawa o powszechnym ubezpieczeniu zdrowotnym została zastąpiona ustawą z dnia 23 stycznia 2003 r. o powszechnym ubezpieczeniu w Narodowym Funduszu Zdrowia ${ }^{3}$. Mimo że ustawodawca po raz kolejny dokonał zmiany w systemie opieki zdrowotnej poprzez likwidację 17 kas chorych i powołanie jednej instytucji zajmującej się zapewnieniem świadczeń zdrowotnych dla osób ubezpieczonych, tj. Narodowego Funduszu Zdrowia, składka zdrowotna została zachowana, stanowiąc jego przychód.

1 Tekst jedn. Dz.U. z 2008 r. Nr 164, poz. 1027 (dalej powoływana jako ustawa); ustawa ta uchyliła ustawę z dnia 23 stycznia $2003 \mathrm{r}$. o powszechnym ubezpieczeniu zdrowotnym w Narodowym Funduszu Zdrowia.

2 Dz.U. Nr 28, poz. 153, ze zm.; ustawa ta weszła w życie 1 stycznia 1999 r.

3 Dz.U. Nr 45, poz. 391, ze zm. 
Ustawa o powszechnym ubezpieczeniu zdrowotnym została zastąpiona ustawą o świadczeniach opieki zdrowotnej finansowanych ze środków publicznych, która obowiązuje obecnie. W świetle tej ustawy finansowanie świadczeń opieki zdrowotnej również zostało oparte o przychody ze składek ubezpieczonych.

Zgodnie rocznym planem finansowym NFZ na 2014 rok przychody z tytułu składek mają wynieść ponad 63 mld zł, a przychody ogółem prawie $67 \mathrm{mld} \mathrm{z}^{4}$. Składka na ubezpieczenie zdrowotne jest zatem obecnie głównym źródłem finansowania ochrony zdrowia w Polsce. Należy wskazać, że składka zdrowotna nie jest jedynym źródłem finansowania świadczeń opieki zdrowotnej. Obok niej należy również wskazać środki publiczne przekazane jako wydatki budżetów jednostek samorządu terytorialnego oraz wydatki budżetu państwa. Mającym coraz większe znaczenie źródłem finansowania ochrony zdrowia są środki prywatne gospodarstw domowych przeznaczane na prywatną opiekę zdrowotną bądź na świadczenia zdrowotne, które nie są finansowane ani przez NFZ, ani przez budżet państwa. Obecnie wskazane wyżej źródła stanowią stosunkowo niewielki element systemu finansowania świadczeń zdrowotnych w porównaniu do przychodów uzyskiwanych ze składki zdrowotnej.

Co do zasady każda osoba podlegająca obowiązkowemu ubezpieczeniu zdrowotnemu jest zobowiązana do zapłaty składki zdrowotnej w odpowiednio obliczonej wysokości. Jednakże ustawodawca przewidział możliwość nieopłacania składki przez określone ustawowo podmioty przy jednoczesnym spełnianiu przez nie wskazanych warunków.

W literaturze nie zdefiniowano dotychczas pojęcia składki na ubezpieczenie zdrowotne. Składka zdrowotna jako danina publiczna swoją konstrukcją przypomina składkę na ubezpieczenie emerytalne, choć istnieją pomiędzy nimi zasadnicze różnice. W związku z tym na potrzeby niniejszego opracowania można posłużyć się doktrynalną definicją składki na ubezpieczenie emerytalne, dostosowując ją jednak do konstrukcji prawnej składki zdrowotnej. Odnosząc próby definiowania składki na

4 Plan finansowy NFZ na 2014 r. stanowiący załącznik do zarządzenia nr 46/2013/DEF Prezesa Narodowego Funduszu Zdrowia z dnia 30 sierpnia 2013 r. w sprawie zmiany planu finansowego Narodowego Funduszu Zdrowia na 2014 rok (www.nfz.gov.pl). 
ubezpieczenia społeczne do ubezpieczenia zdrowotnego, przyjąć należy, że składka zdrowotna jest świadczeniem pieniężnym, przymusowym, celowym, odpłatnym i bezzwrotnym ${ }^{5}$. Bezzwrotność składki polega na tym, że opłacona zgodnie z przepisami składka nie podlega zwrotowi ${ }^{6}$. W podobny sposób składki były definiowane w poprzednio obowiązującym stanie prawnym. Jako ich wyróżniające cechy wskazywano przymusowość, celowość, odpłatność oraz pieniężny charakter ${ }^{7}$.

Celem niniejszego opracowania jest próba scharakteryzowania wprowadzonych przez ustawodawcę ulg dla ściśle wskazanych podmiotów. W literaturze brak szerszego omówienia niniejszych zagadnień, mimo że mają one istotne znaczenie przede wszystkim dla prowadzenia działalności gospodarczej przez osoby mogące korzystać omawianych ulg. Ustawodawca wprowadził ulgę w zapłacie składki zdrowotnej dla emerytów i rencistów oraz osobno dla osób niepełnosprawnych.

\section{Ulgi dla emerytów i rencistów}

Art. 66 ustawy o świadczeniach zdrowotnych finansowanych ze środków publicznych zawiera katalog podmiotów, które podlegają obowiązkowi ubezpieczenia zdrowotnego. Zgodnie z art. 66 ust. 1 pkt 16 ustawy obowiązkowemu ubezpieczeniu zdrowotnemu podlegają m.in. osoby pobierające emeryturę lub rentę. Obowiązkowi ubezpieczenia zdrowotnego podlegają również osoby prowadzące działalność pozarolniczą (art. 66 ust. 1 pkt 1 lit. c).

Ustawa o świadczeniach zdrowotnych wprowadza zasadę, zgodnie z którą w przypadku, gdy ubezpieczony uzyskuje przychody z więcej niż jednego tytułu do objęcia obowiązkiem ubezpieczenia zdrowotnego, o którym mowa w art. 66 ust. 1 ustawy, składka na ubezpieczenie zdrowotne opłacana jest z każdego z tytułów odrębnie. Zasada ta wynika wprost $\mathrm{z}$ art. 82 ust. 1.

\footnotetext{
5 I. Jędrasik-Jankowska, Ubezpieczenia emerytalne. Trzy filary, Warszawa 2001, s. 73.

6 J. Wantoch-Rekowski, Składki na ubezpieczenia społeczne i ich charakter prawny, „Gdańskie Studia Prawnicze” 2007, nr 16, s. 350-351.

7 W. Szubert, Ubezpieczenia społeczne. Zarys systemu, Warszawa 1987, s. 217.
} 
W związku z tym każda osoba pobierająca świadczenie emerytalne i rentowe oraz jednocześnie prowadząca działalność gospodarczą, z której uzyskuje jakiekolwiek przychody, lub współpracująca z taką osobą jest zobowiązana do zapłaty składki zdrowotnej z tytułu pobierania świadczeń z ubezpieczenia społecznego oraz odrębnie z tytułu prowadzenia działalności gospodarczej.

Na podstawie art. 8 ust. 6 pkt 1-4 ustawy z dnia 13 października 1998 r. o systemie ubezpieczeń społecznych ${ }^{8}$ za osobę prowadzącą pozarolniczą działalność uważa się osobę prowadzącą pozarolniczą działalność gospodarczą na podstawie przepisów o działalności gospodarczej lub innych przepisów szczególnych; twórcę i artystę; osobę prowadzącą działalność w zakresie wolnego zawodu w rozumieniu przepisów o zryczałtowanym podatku dochodowym od niektórych przychodów osiąganych przez osoby fizyczne lub z której przychody są przychodami z działalności gospodarczej w rozumieniu przepisów o podatku dochodowym od osób fizycznych; wspólnika jednoosobowej spółki z ograniczoną odpowiedzialnością oraz wspólników spółki jawnej, komandytowej lub partnerskiej. Za osobę prowadzącą pozarolniczą działalność uważa się także osobę prowadzącą publiczną lub niepubliczną szkołę, inną formę wychowania przedszkolnego, placówkę lub ich zespół, na podstawie przepisów o systemie oświaty.

W art. 82 ust. 8 ustawy wprowadzono możliwość nieopłacania składki na ubezpieczenie zdrowotne wyłącznie z tytułu prowadzenia pozarolniczej działalności gospodarczej lub współpracy z osobą prowadzącą taką działalność przez osoby podlegające obowiązkowi ubezpieczenia zdrowotnego pobierające świadczenie emerytalne lub rentowe, jeżeli ich dochody miesięcznie nie przekraczają kwoty minimalnego wynagrodzenia za pracę. Zasady ustalania minimalnego wynagrodzenia określa ustawa z dnia 10 października 2002 r. o minimalnym wynagrodzeniu za pracę ${ }^{9}$.

Dz.U. z 2013 r. poz. 1442 ze zm.

Dz.U. Nr 200, poz. 1679. Zgodnie z Rozporządzeniem Rady Ministrów z dnia 11 września 2013 r. w sprawie wysokości minimalnego wynagrodzenia za pracę w 2014 r. (Dz.U. z 2013 r. poz. 1074) wydanym na podstawie ww. ustawy, minimalne wynagrodzenie za pracę wynosi obecnie 1680 zł. 
Jest to podstawowy warunek, który muszą spełnić emeryci i renciści, aby móc skorzystać z przewidzianego w przepisach ustawy zwolnienia.

Zgodnie z art. 82 ust. 1 pkt 1 i 2 ustawy osoby pobierające świadczenia emerytalne lub rentowe, których wysokość nie przekracza minimalnego wynagrodzenia za pracę, nie muszą odprowadzać składek na ubezpieczenie zdrowotne z tytułu prowadzenia pozarolniczej działalności gospodarczej, jeżeli nadto spełnią jedno z następujących kryteriów. Pierwszym z nich jest uzyskiwanie dodatkowych przychodów z prowadzenia pozarolniczej działalności w wysokości nieprzekraczającej miesięcznie 50\% kwoty najniższej emerytury. W 2014 r. najniższa emerytura wynosi 844,45 zł miesięcznie ${ }^{10}$. Kwota ta jest progiem granicznym zarówno dla osób pobierających świadczenie emerytalne, jak i dla osób otrzymujących rentę. Ustawodawca nie różnicuje tutaj sytuacji rencistów, których minimalna kwota świadczenia rentowego jest inna w zależności od tytułu, z jakiego otrzymują oni świadczenie.

W art. 82 ust. 8 pkt 1 ustawy jednoznacznie wskazano, że chodzi wyłącznie o przychody, a nie dochody uzyskiwane z prowadzonej przez emeryta lub rencistę działalności. W związku z tym osoba pobierająca świadczenie emerytalne lub rentowe, aby móc korzystać z analizowanego zwolnienia, nie może uzyskiwać przychodów z prowadzenia działalności pozarolniczej przekraczających kwotę 422,22 zł miesięcznie.

Tak określony przez ustawodawcę próg uzyskiwania przychodów, którego przekroczenie przez przedsiębiorcę powoduje utratę możliwości skorzystania ze zwolnienia w danym miesiącu, jest zbyt niski. Uzyskiwanie samego przychodu w kwocie 422 zł miesięcznie w zasadzie nie powinno stanowić dla przedsiębiorcy większego problemu. Należy pamiętać, że przy większości rodzajów prowadzonej pozarolniczej działalności gospodarczej koszty uzyskania przychodu w przeważającej części przypadków przekraczają kwotę 422 zł miesięcznie. W takich sytuacjach emeryci i renciści prowadzący pozarolniczą działalność musieliby wykazywać

10 Komunikat Prezesa Zakładu Ubezpieczeń Społecznych z dnia 18 lutego 2014 r. w sprawie kwoty najniższej emerytury i renty, dodatku pielęgnacyjnego i dodatku dla sierot zupełnych oraz kwot maksymalnych zmniejszeń emerytur i rent (M.P., poz. 165). 
stratę z tego źródła przychodu, aby móc skorzystać ze zwolnienia, o którym mowa w art. 82 ust. 8 ustawy.

Zwolnienie przewidziane $\mathrm{w}$ analizowanych przepisach w obecnym stanie prawnym będzie miało zastosowanie wyłącznie w stosunku do tych rodzajów pozarolniczej działalności gospodarczej, w których przedsiębiorca ponosi bardzo niskie koszty uzyskania przychodów. Wówczas jego dochody będą zbliżone do przychodów, osiągnie on zysk z prowadzonej działalności gospodarczej i jednocześnie skorzysta ze zwolnienia z opłacania składki zdrowotnej z tytułu prowadzenia pozarolniczej działalności.

Kwota składek na ubezpieczenie społeczne w 2014 r. wynosi 661,92 zł ${ }^{11}$. Osoby pobierające świadczenie emerytalne poddają się często dobrowolnemu ubezpieczeniu społecznemu z tytułu prowadzenia działalności gospodarczej w celu zwiększenia w kolejnych latach wysokości ich emerytury. W takich przypadkach osoby pobierające świadczenia emerytalne i prowadzące jednocześnie działalność gospodarczą, a chcące skorzystać ze zwolnienia z zapłaty składki na ubezpieczenie zdrowotne, nie będą mogły osiągnąć nawet takiego przychodu, który pozwoliłby im na sfinansowanie dobrowolnych składek na ubezpieczenia społeczne. Jeżeli takie osoby będą chciały zachować analizowane zwolnienie z opłacania składek na ubezpieczenia zdrowotne, będą zmuszone do obniżenia swoich przychodów. Z ekonomicznego punktu widzenia wydaje się to nieracjonalne, tym bardziej że jednocześnie będą one musiały sfinansować składki na ubezpieczenia społeczne z dochodów uzyskiwanych z innych tytułów.

Podsumowując dotychczasowe rozważania, należy stwierdzić, że zwolnienie, o którym mowa w art. 82 ust. 8 ustawy o świadczeniach opieki zdrowotnej finansowanych ze środków publicznych, zostało zarezerwowane wyłącznie dla osób pobierających świadczenie emerytalne i ren-

11 Zgodnie z art. 18 ust. 8 ustawy o systemie ubezpieczeń społecznych podstawę wymiaru składek na ubezpieczenia emerytalne i rentowe osób prowadzących pozarolniczą działalność stanowi zadeklarowana kwota, nie niższa jednak niż 60\% prognozowanego przeciętnego wynagrodzenia miesięcznego, o którym mowa w art. 19 ust. 10 powoływanej ustawy. Zgodnie z obwieszczeniem Ministra Pracy i Polityki Społecznej z dnia 13 grudnia 2013 r. w sprawie kwoty ograniczenia rocznej podstawy wymiaru składek na ubezpieczenia emerytalne i rentowe w roku 2014 oraz przyjętej do jej ustalenia kwoty prognozowanego przeciętnego wynagrodzenia (M.P., poz. 1028) prognozowane przeciętne wynagrodzenie miesięczne w 2014 r. wynosi 3746 zł. 
towe, osiągających jednocześnie przychód z pozarolniczej działalności gospodarczej przy niskich kosztach jego uzyskania. Tylko wtedy emeryci i renciści uzyskaliby pożądany efekt z wprowadzenia art. 82 ust. 8 ustawy w postaci uzyskiwania odczuwalnego dla nich zysku oraz możliwości nieopłacania składki na ubezpieczenie zdrowotne.

Kolejną przesłanką obok osiągania przychodu w określonej wysokości do zastosowania art. 82 ust. 8 ustawy jest opłacanie przez emeryta lub rencistę podatku dochodowego $\mathrm{w}$ formie karty podatkowej. Osoba pobierająca świadczenie emerytalne lub rentowe opłacająca podatek w takiej formie może osiągać przychody z prowadzenia działalności gospodarczej wyższe niż 50\% najniższej emerytury. Przesłanki z art. 82 ust. 8 pkt 1 i 2 ustawy są od siebie niezależne. Wystarczy, aby ubezpieczony spełnił którąkolwiek z nich, i wówczas może skorzystać ze zwolnienia w opłacaniu składki na ubezpieczenie zdrowotne.

W przepisie art. 82 ust. 8 pkt 2 ustawodawca wskazuje wyłącznie na opodatkowanie w formie karty podatkowej. W związku z tym emeryci lub renciści podlegający możliwości skorzystania z innych uproszczonych form opodatkowania nie mogą skorzystać ze zwolnienia z opłacania składki na ubezpieczenie zdrowotne. Należy zauważyć, że taka konstrukcja przepisu daje możliwość skorzystania ze zwolnienia tylko tym przedsiębiorcom, którzy prowadzą określoną w ustawie z dnia 20 listopada 1998 r. o zryczałtowanym podatku dochodowym od niektórych przychodów osiąganych przez osoby fizyczne ${ }^{12}$ działalność gospodarczą przewidzianą w załączonych do niej tabelach. Osoby wykonujące inną działalność, niż ta, która może być opodatkowana kartą podatkową, nie będą mogły skorzystać ze zwolnienia.

Jak z powyższego wynika, zwolnienie z art. 82 ust. 8 zostało przewidziane dla stosunkowo niewielkiej grupy emerytów i rencistów prowadzących pozarolniczą działalność gospodarczą. Wynika to zapewne z zasad ubezpieczenia zdrowotnego, tj. równego traktowania, solidarności społecznej oraz zapewnienia równego dostępu do świadczeń opieki zdrowotnej (art. 65 ustawy). Jednakże tak skonstruowane przesłanki do skorzysta-

12 Dz.U. Nr 144, poz. 930 ze zm. 
nia z analizowanego zwolnienia powodują, że jest ono rzadko wykorzystywane i tylko w przypadku osiągania niskich przychodów niezależnie od wysokości dochodów. Pozytywnym elementem zwolnienia z zapłaty składki zdrowotnej jest to, że można z niego skorzystać w poszczególnych miesiącach roku, jeżeli zostaną w nich spełnione wyżej omówione przesłanki. Brak jest konieczności składania jakichkolwiek deklaracji w tym zakresie oraz określania z góry okresu, w którym przedsiębiorca chce skorzystać ze zwolnienia. Zwolnienie to jest stosowane ad hoc. Jeżeli w danym miesiącu przedsiębiorca nie spełnia warunków do skorzystania ze zwolnienia, to $\mathrm{w}$ innych miesiącach roku kalendarzowego może $\mathrm{z}$ takiego zwolnienia skorzystać (wówczas, gdy w danym miesiącu zrealizuje warunki określone w art. 82 ust. 8 ustawy).

\section{Ulgi dla osób niepełnosprawnych}

Zgodnie z art. 82 ust. 9 ustawy o świadczeniach opieki zdrowotnej finansowanych ze środków publicznych składka na ubezpieczenie zdrowotne nie jest opłacana przez osobę zaliczoną do umiarkowanego lub znacznego stopnia niepełnosprawności od tytułu do objęcia obowiązkiem ubezpieczenia zdrowotnego, o którym mowa w art. 66 ust. 1 pkt 1 lit. c, jeżeli osoba ta spełni kryteria przewidziane w ustawie. Przesłanki, od realizacji których zależy możliwość skorzystania ze zwolnienia w zapłacie składki zdrowotnej, zostały uregulowane przez ustawodawcę w analogiczny sposób do zwolnienia z zapłaty składki osób pobierających świadczenie emerytalne lub rentowe, z zastrzeżeniem, że aby skorzystać ze zwolnienia, osoba niepełnosprawna nie musi osiągać przychodów lub dochodów w ograniczonej wysokości z innych tytułów do ubezpieczenia zdrowotnego.

W związku z tym uwagi poczynione do art. 82 ust. 8 ustawy będą aktualne również na gruncie zwolnienia z zapłaty składki zdrowotnej na podstawie art. 82 ust. 9. Wątpliwości budzi uzależnienie zastosowania zwolnienia od uzyskiwania przychodów z działalności gospodarczej w miesięcznej wysokości nieprzekraczającej 50\% kwoty najniższej emerytury. Nieuzasadnionym wydaje się uwarunkowanie możliwości skorzystania ze zwolnienia z art. 82 ust. 9 ustawy (porównując osiągany przy- 
chód do wysokości najniższej emerytury). Skoro osoba zaliczana do umiarkowanego lub znacznego stopnia niepełnosprawności nie pobiera świadczenia emerytalnego, to nie powinno się uzależniać korzystania ze zwolnienia z zapłaty składki zdrowotnej od wysokości świadczenia, którego ta osoba nie pobiera. Bardziej uzasadnionym wydawać się może uzależnienie zastosowania omawianego zwolnienia od wysokości kwot uzyskiwanych przez osoby niepełnosprawne z uwagi na ich stan zdrowia oraz ewentualną sytuację materialną.

Osoby zaliczane do umiarkowanego lub znacznego stopnia niepełnosprawności mogą także skorzystać z dodatkowej ulgi przewidzianej w przepisach ustawy o świadczeniach opieki zdrowotnej finansowanych ze środków publicznych. Zgodnie z art. 82 ust. 10 ustawy składka na ubezpieczenie zdrowotne jest opłacana w wysokości nieprzekraczającej kwoty należnej zaliczki na podatek dochodowy od osób fizycznych, w przypadku gdy osoba zaliczona do umiarkowanego lub znacznego stopnia niepełnosprawności uzyskuje przychód jedynie z tytułu objęcia obowiązkiem ubezpieczenia zdrowotnego, o którym mowa w art. 66 ust. 1 pkt 1 lit. c (działalność pozarolnicza).

Powyższa ulga dotyczy wyłącznie osób niepełnosprawnych, które opłacają podatek dochodowy na zasadach ogólnych. Zgodnie z art. 24 ustawy o zryczałtowanym podatku dochodowym od niektórych przychodów osiąganych przez osoby fizyczne podatnicy prowadzący działalność opodatkowaną w formie karty podatkowej są zwolnieni m.in. od obowiązku wpłacania zaliczek na podatek dochodowy. Również podatnicy opodatkowani ryczałtem od przychodów ewidencjonowanych nie są zobowiązani do odprowadzania na rachunek właściwego urzędu skarbowego zaliczki na podatek dochodowy. Zgodnie z art. 21 powoływanej ustawy podatnicy są zobowiązani za każdy miesiąc obliczać ryczałt od przychodów ewidencjonowanych i wpłacać go na rachunek urzędu skarbowego w terminie do 20. dnia następnego miesiąca. Miesięczny ryczałt od przychodów ewidencjonowanych nie stanowi zaliczki na podatek dochodowy w rozumieniu art. 82 ust. 10 ustawy o świadczeniach opieki zdrowotnej. W związku z tym osoby opłacające podatek dochodowy w formie ryczał- 
tów nie mają możliwości skorzystania z ulgi w zapłacie składki zdrowotnej, o której mowa w art. 82 ust. 10 ustawy o świadczeniach opieki zdrowotnej.

W analizowanym zakresie badań istotne znaczenie ma fakt, że niepełnosprawny przedsiębiorca nie może uzyskiwać jakiegokolwiek przychodu z innych tytułów, niż pozarolnicza działalność gospodarcza. Jeżeli osoba niepełnosprawna otrzymuje przychód z innych tytułów do objęcia ubezpieczeniem zdrowotnym, wówczas nie może ona obniżyć składki zdrowotnej do wysokości kwoty należnej zaliczki na podatek dochodowy.

\section{Zakończenie}

Przedstawione powyżej ulgi w zapłacie składki zdrowotnej dla przedsiębiorców nie mają istotnego znaczenia fiskalnego dla planu finansowego NFZ, którego przychodami są należne składki zdrowotne oraz odsetki od nieopłaconych w terminie składek (zgodnie z art. 116 ust. 1 i 2 ustawy o świadczeniach ochrony zdrowia finansowanych ze środków publicznych). Przesłanki ich zastosowania powodują, że niewiele osób podlegających obowiązkowemu ubezpieczeniu zdrowotnemu może z nich skorzystać. Wskazać należy, że tylko dwie grupy społeczne, jakimi są emeryci i renciści oraz osoby zaliczane do umiarkowanego lub znacznego stopnia niepełnosprawności, które nadto muszą prowadzić działalność gospodarczą, mogą być zwolnione z zapłaty składki zdrowotnej lub mogą ją obniżyć do wysokości zaliczki na podatek dochodowy i tylko z tytułu prowadzenia pozarolniczej działalności.

Niewątpliwie taka konstrukcja zakresu podmiotowego analizowanych ulg determinowana jest zasadami ubezpieczenia zdrowotnego skatalogowanymi w art. 65 ust. 1 i 2 ustawy. W szczególności wpływ na zakres podmiotowy ulg ma zasada solidarności społecznej. Wynika z niej, że generalnie każda osoba podlegająca obowiązkowi ubezpieczenia zdrowotnego powinna opłacać składkę zdrowotną odrębnie od każdego z tytułów, z których objęta jest ubezpieczeniem, co ma na celu zapewnienie funkcjonowania systemu i zagwarantowanie dostępu do świadczeń zdrowotnych wszystkim ubezpieczonym. 
Ustawowe przesłanki do zastosowania ulg w zapłacie składki dla przedsiębiorców zostały określone bardzo sztywno. Powoduje to, że wyżej opisane grupy społeczne mogą z nich korzystać praktycznie w wyjątkowych przypadkach. Przykładem restrykcyjnego kształtu ulg jest m.in. wskazanie w przepisach art. 82 ust. 8 ustawy określonej wysokości uzyskiwanego przez przedsiębiorcę przychodu jako przesłanki warunkującej możliwość skorzystania z ulgi w danym miesiącu. Dla ubezpieczonych dużo bardziej korzystnym rozwiązaniem byłoby zastąpienie przez ustawodawcę przychodu dochodem. W obecnym stanie prawnym, aby skorzystać z ulg, przedsiębiorcy nie mogą odliczać kosztów uzyskania przychodu, tak jak ma to miejsce w przypadku obliczania dochodu dla celów podatkowych. W przypadku zmiany przychodu na dochód osoby prowadzące działalność pozarolniczą, której specyfiką jest ponoszenie wysokich kosztów uzyskania przychodu, mogłyby skorzystać z przewidzianych w ustawie ulg. Ewentualnym rozwiązaniem byłoby podwyższenie progu przychodu, jakim jest obecnie 50\% kwoty najniżej emerytury, co jednak może w sposób bardziej istotny wpłynąć na plan finansowy NFZ.

Wątpliwości może budzić uzależnienie możliwości skorzystania z ulgi przez osoby zaliczane do umiarkowanego lub znacznego stopnia niepełnosprawności. Warunkowanie zastosowania ulgi od uzyskiwania przychodów z pozarolniczej działalności w wysokości połowy kwoty najniższej emerytury wydaje się nieprzystające do sytuacji prawnej i ekonomicznej osób niepełnosprawnych. Być może bardziej trafnym rozwiązaniem byłoby uzależnienie zastosowania ulgi od wysokości lub części zasiłku pielęgnacyjnego przyznawanego osobom niepełnosprawnym.

Niezrozumiałym wydaje się także preferowanie przez ustawodawcę przy konstruowaniu wyżej opisanych ulg przedsiębiorców, którzy prowadząc działalność gospodarczą, stosują uproszczone formy opodatkowania, a zwłaszcza kartę podatkową. Przedsiębiorcy prowadzący tylko niektóre kategorie pozarolniczej działalności mogą rozliczać się w postaci ryczałtów, co prowadzi do tego, że osoby prowadzące określony rodzaj działalności nie mogą skorzystać z przewidzianych w ustawie ulg, nawet jeśli spełniają wszystkie pozostałe kryteria. 
Podsumowując, ulgi w zapłacie składki zdrowotnej zostały skonstruowane przez ustawodawcę w sposób bardzo restrykcyjny. Ogranicza to możliwość szerszego skorzystania z nich przez grupy społeczne, do których są one kierowane. Niewątpliwie taki kształt przepisów warunkowany jest troską ustawodawcy o zabezpieczenie prawidłowego funkcjonowania systemu ochrony zdrowia. Zmiana kryteriów stosowania ulg zmniejszyłaby wpływy ze składek zdrowotnych, natomiast ułatwiłaby prowadzenie działalności gospodarczej ubezpieczonym. Jednak ustawodawca na gruncie ubezpieczenia zdrowotnego w sposób oczywisty przedkłada finanse NFZ nad interes ubezpieczonego.

\section{Bibliografia:}

Jędrasik-Jankowska I., Ubezpieczenia emerytalne. Trzy filary, LexisNexis, Warszawa 2001.

Szubert W., Ubezpieczenia społeczne. Zarys systemu, PWN, Warszawa 1987.

Wantoch-Rekowski J., Składki na ubezpieczenia społeczne i ich charakter prawny, „Gdańskie Studia Prawnicze” 2007, nr 16, s. 349-358. 